\title{
Employability of international students: Strategies to enhance their experience on work-integrated learning (WIL) programs
}

\author{
Thanh Pham $^{1 a}$, Eisuke Saito ${ }^{1 b}$, Dat Bao ${ }^{1}$, Raqib Chowdhury ${ }^{1}$ \\ thanh.t.pham@monash.edu; eisuke.saito@monash.edu; dat.bao@monash.edu; \\ raqib.chowdhury@monash.edu \\ ${ }^{1}$ Faculty of Education, Monash University \\ ahttps://orcid.org/0000-0001-7001-5011; ${ }^{\text {bhttps://orcid.org/0000-0002-1689-1210 }}$
}

\begin{abstract}
This paper presents a systematic qualitative review of relevant literature, documents and reports, and critically discusses issues facing international students undertaking workintegrated learning (WIL) activities as part of their higher education in Australia. Initiatives utilised to better support international students on these WIL placements are described. Based on an evaluation of the data reviewed, the discussion highlights two main challenges to international students' employment experiences: a limited competence in English communication, and a limited understanding of the local working context. In seeking explanations for the above, the authors identified factors such as inadequate student-entry procedures, limited opportunities for socialisation, limited input in cultural protocols, and the lack of soft-skills training. The recommended solutions include more uniformity between government and employer sectors, increased acceptance and support for multicultural diversity, an openness towards diverse ways of thinking, and an enhancement of training in diverse communication styles.
\end{abstract}

Keywords: work-integrated learning, employability, international students, Australia, higher education

\section{Introduction}

Although Australia is striving to build a knowledge-based economy founded on a highly skilled workforce (Minister for Innovation, Industry, Science and Research, 2011), the domestic workforce remains insufficient to meet the demand for skilled labour in a number of areas. For instance, Australia has a significant shortage of STEM graduates. The proportion of Australia university students graduating with STEM qualifications is 16 per cent (ABC News, 2015), which is significantly lower than in other nations such as Singapore and China which have about 50 per cent of their students graduating from various STEM fields (ABC News, 2015). Australia also has a high demand for teachers, especially when the number of students is predicted to increase by 26 per cent by 2022 (School Governance, 2016).

To fill these gaps, the Skilled Migration Policy was launched in 2009 to attract skilled workers from overseas to Australia. Despite this, it has been reported that a large percentage of newly arrived immigrants have not been able to find suitable jobs after settling in Australia. Roddick (2014), for example, reported that 40 per cent of overseas teachers experienced significant periods of unemployment since their arrival, although it is unclear if this percentage includes those who are waiting for their overseas qualifications to be recognised in Australia. The main 
reason contributing to their difficulty in finding a job was that their home education, skills and experiences were not recognised and rewarded adequately in Australia (Teacher, 2014). A more effective strategy to fill this shortage of teachers would be to employ international graduates of Australian universities which comprise over 24 per cent of Australian universities' student population (Australian Universities, 2017). When employed, these international graduates are known to demonstrate a range of valued qualities including domestically relevant educational qualifications and skills, locally recognised credentials, familiarity with the host culture, as well as host-country language ability (Hawthorne, 2014). Indeed, these factors can advantage international graduates in being successful in their employment in Australia over recently arrived migrants without local education and/or qualifications.

A landmark shift in Australia's policy in recognising the role of international students in the Australian workforce occurred with the introduction of the National Strategy for International Education 2025, launched by the Australian Government in April 2016. The main focus of this Strategy was to propose approaches for maintaining and developing the reputation of international education. The Strategy highlighted the need for higher education providers to enhance the employability of graduates because Australia's reputation for providing highquality, world-class education rested on the quality and employability of graduates; and that relevant local community and industry needed to be more engaged in supporting the fieldwork experiences of international students. More specifically, the Strategy acknowledged the need to expand the potential, scale and breadth of relevant WIL opportunities for international students and graduates (DET 2015, p. 42). In Australian higher education, WIL is currently the main avenue for students to gain hands-on experiences. Tran and Soejatminah (2016) reported that WIL has increasingly become an important component of institutions' strategies in positioning themselves in the competitive international education market. The following sections present a brief history of WIL and discuss the need to understand and improve international students' engagement with and in WIL.

\section{Understanding WIL}

Work-integrated learning (WIL) is not a new concept. Historically, various WIL models have been developed to respond to the demands of the labour market. Prior to the 1960s, the 'apprenticeship model' was used to illustrate the relationship between academic institutions and the workplace (Bines \& Watson, 1992; Humphreys, Greenan, \& Mcllveen, 1997). According to this model, intellectual and theoretical frameworks were counted as the university's responsibility, whereas the workplace was responsible for training employees to apply what they had learned at university. However, this model resulted in a scant approach to addressing unemployment with graduates obtaining only theoretical knowledge, leading to their inability to handle their work, giving the university a poor reputation amongst employers (Steedman, Gospel, Ryan, \& Apprenticeship, 1998). To improve this situation, a 'technocratic model' was introduced which emphasised a combination of a knowledge base provided by a university with the application of that knowledge base supervised in the workplace (Bines \& Watson, 1992). After the birth of this model, academic institutions actively looked for and partnered with industries to provide training for students prior to graduation. In the last two decades, and in response to rapid changes in today's global workplaces and the increased emphasis on independent, active and critical learning, a new 'post-technocratic' model has emerged (Castle, Holloway, \& Race, 1998). The key aspect of this model is to require graduates to develop critical and reflective skills, and then develop their own practices to respond to constant changes.

Universities worldwide are currently applying both the 'technocratic" and 'post-technocratic' models to different degrees. In practice, WIL is offered as a component of a course, most commonly in the form of placement and placement-related activities. Raelin (2010) argues that WIL incorporates two fundamental dimensions: theory and practice modes of learning, and explicit and tacit forms of knowledge (p.13). While the structure of WIL programs does vary, they mainly include activities such as industry-based projects, placements, internships, 
and service learning, organised both locally and internationally. The length and scope of these activities vary amongst institutions, disciplines and year levels. The main purpose of these activities is to create opportunities for students to gain hands-on experience in a real-world environment (Tran \& Soejatminah, 2016, p. 341). In WIL programs students have opportunities to obtain and enrich their insights into the real world within the scope of their disciplines. Gribble (2014) claims that WIL activities benefit students in various areas because the students can practise their technical and non-technical skills in an approved setting which provides a suite of offerings, including career-management provision, employability skilldevelopment, and the cultivation of life skills and civic responsibility, which are designed to enhance graduate employability (cited in Jackson, 2016, p. 39).

There is a plethora of research on the nature of WIL and issues facing students when participating in such activities. A large volume of research has reported various benefits of students when participating in WIL. For instance, Crebert, Bates, Bell, Patrick and Cragnolini (2004) and Ryan, Toohey and Hughes (1996) clearly evidenced that WIL could enhance students' employability because they could obtain a set of 'real world' skills. Nicol (2013), Little and Harvey (2006), Anderson and Green (2006), Barton et al. (2017), Nicholls and Walsh (2007) and Gribble and McRae (2015) similarly reported a wide range of non-technical skills that students could achieve through WIL. These included active listening and reasoning skills, maturity, emotional intelligence, team-building, negotiation, communication and interpersonal skills. Hattie, Marsh, Neill and Richards (1997) further claimed that experiences obtained in WIL in turn helped students to learn more effectively in their disciplines because they could become more critical with their learning based on problem solving and analysing skills obtained in the real world. Reddy and Moores (2012) confirmed that these academic benefits can be seen regardless of course subject, gender, ethnicity and socioeconomic status. All of these technical and non-technical knowledge and skills have been identified as important drivers of employability (Griffiths \& Guile, 2003).

By contrast, very little has been known about the role of international students in WIL (Gribble \& Blackmore, 2012; Orrell, 2011; Patrick, Peach, Pocknee, Webb, Fletcher, \& Pretto, 2008). The main reason contributing to this is that this cohort has historically been seen as those coming to Australia for education, but not necessarily to become integrated into the workforce. As discussed above, the National Strategy has marked a significant shift in recognising the important role of international students in Australia's workforce. There is, therefore, a need for further investigation of international students' engagement in WIL and what can be done to help this cohort overcome existing problems. By providing a systematic review of research on international students' WIL experiences, the discussion teases out a number of language and cultural problems, which are the two major issues facing this particular cohort. The paper also discusses possible solutions as joint efforts of various stakeholders - a perspective hitherto not commonly discussed in the literature.

\section{Research method}

The qualitative research method adopted in this study was that of document analysis. This is an invaluable research approach as it allows researchers to determine convergence of issues and themes and seek validation through different data sources (Bowen, 2009). Cresswell (1998) suggests that extensive data collection from multiple sources is the backbone of qualitative research and enables triangulation or cross validating of information (p.19). Underpinning the selection of documents were the following research questions:

- What are the issues which face international students participating in WIL?

- What initiatives are used to support international students during WIL placements?

- What are the barriers to employment for international students in Australia?

- What measures might mitigate the difficulties encountered? 


\section{Data collection and analysis}

A systematic qualitative review of the research literature, relevant documents and reports published after 1999 was conducted with a focus on Asian international students participating in WIL organised in English-speaking settings. As discussed above, for this research, the concept of WIL refers to programs where international students practice their working skills and receive training from prospective employers.

Relevant scholarly journal articles were identified through a thorough search of electronic databases, including Educational Resources Information Centre (ERIC), Psychological Abstracts (PA), Dissertation Abstracts International (DAl), and the Social Sciences Citation Index (SSCI). To ensure high-quality resources and a sharp focus, the search primarily targeted peer-refereed journal articles, using the combination of the following keywords: 'Australia', 'Asian international students', 'work-based learning', 'work-integrated learning', 'employability', 'university', 'higher education', 'placement' and 'internship'. The exclusion criteria for this review included: studies of Western students in Asian settings, research on students on exchange programs and research without empirical data.

The review consisted of two stages. First, a total of 50 journal publications were identified within the subject area and 14 articles were identified as having met the inclusion criteria. These publications were interrogated. An inductive approach was applied to analyse the data to find problems facing international students on WIL. First, the researchers read and re-read the findings of the reviewed studies to identify and group problems that international students faced into themes. Then, themes that referred to the same problem were grouped into a bigger theme. After categorizing all problems and grouping them in themes, a list of themes referring to various problems facing international students emerged. However, within the scope of this paper, only the two biggest themes referring to two major issues facing international students were reported: language barriers and the lack of local culture understanding.

In addition to the review of scholarly journal articles, a search of media stories, surveys and interviews with academics and employers published in reputed newspapers and websites such as the Australian Broadcasting Corporation (ABC) was undertaken. The authors considered these data credible and valid because these online newspapers and websites rely on well-accepted ethical journalistic procedures and multi-source fact-checking to judge the information and examine for correspondent integrity prior to publication and public dissemination.

\section{Results}

Table 1 presents the studies chronologically by year of publication. This table includes study names of researchers, year of study, title of the report, discipline(s), research approaches used to collect data and main findings. 
Table 1: Fourteen Studies on Experiences of International Students on WIL

\begin{tabular}{|c|c|c|c|c|c|}
\hline No & Authors \& year & Title of publication & Discipline(s) & $\begin{array}{c}\text { Data } \\
\text { collection } \\
\text { method }\end{array}$ & Main findings \\
\hline 1 & $\begin{array}{l}\text { Barton, G., Hartwig, } \\
\text { K., Bennett, D., } \\
\text { Cain, M., Campbell, } \\
\text { M., Ferns, S., } \\
\text { Jones, L., Joseph, } \\
\text { D., Kavanagh, M., } \\
\text { Kelly, A., Larkin, I., } \\
\text { O'Connor, E., } \\
\text { Podorova, A., } \\
\text { Tangen, D., \& } \\
\text { Westerveld, M. } \\
\text { (2015) }\end{array}$ & $\begin{array}{l}\text { Work placement for } \\
\text { international student } \\
\text { programs (WISP): A } \\
\text { model of effective } \\
\text { practice }\end{array}$ & $\begin{array}{l}\text { Psychology } \\
\text { and } \\
\text { education }\end{array}$ & $\begin{array}{l}\text { Semi- } \\
\text { structured } \\
\text { interviews }\end{array}$ & $\begin{array}{l}\text { This research reported two case studies in which two international } \\
\text { students struggled on placements in areas of writing, } \\
\text { competencies to run lessons and self-reflection to make } \\
\text { improvement. The study applied a model of effective practice } \\
\text { identifying these areas and provided strategies for the students to } \\
\text { navigate and improve the problems. The study emphasised the } \\
\text { roles of both the students and the mentors in collaboratively } \\
\text { solving the problems. For the students, they needed to use self- } \\
\text { reflection as the main tool to reflect on their work experiences in } \\
\text { order to reconstruct their professional practice. For the mentors, } \\
\text { they needed to recognise the strengths of the students and } \\
\text { provide constructive feedback to them. }\end{array}$ \\
\hline 2 & $\begin{array}{l}\text { O’Reilly, S. L., \& } \\
\text { Milner, J. (2015) }\end{array}$ & $\begin{array}{l}\text { Supporting culturally } \\
\text { and linguistically } \\
\text { diverse students } \\
\text { during clinical } \\
\text { placement: } \\
\text { Strategies from both } \\
\text { sides of the table. }\end{array}$ & Medical & $\begin{array}{l}\text { Semi- } \\
\text { structured } \\
\text { interviews }\end{array}$ & $\begin{array}{l}\text { The research explored challenges of students on clinical } \\
\text { placements as a core component of most health care degrees. } \\
\text { Semi-structured focus groups with healthcare students }(n=13) \\
\text { and clinical placement supervisors }(n=12) \text { were employed. The } \\
\text { research reported cultural and language issues as one of the } \\
\text { three main barriers facing international students. Strategies } \\
\text { proposed to solve these issues were to: build language and } \\
\text { practical approaches for communication, raise awareness of the } \\
\text { healthcare system (how it interacts with healthcare professions } \\
\text { and how patients access it), and initiate mentoring programs. }\end{array}$ \\
\hline
\end{tabular}

Pham ' T., Saito, E., Bao, D., \& Chowdhury, R. (2018). Employability of international students: Strategies to enhance their experience on work integrated learning (WIL) programs. Journal of Teaching and Learning for Graduate Employability, 9(1), 62-83. 


\begin{tabular}{|c|c|c|c|c|c|}
\hline 3 & $\begin{array}{l}\text { Gribble, C., \& } \\
\text { McRae, N. (2015) }\end{array}$ & $\begin{array}{l}\text { Creating a climate } \\
\text { for global WIL: } \\
\text { Barriers to } \\
\text { participation and } \\
\text { strategies for } \\
\text { enhancing } \\
\text { international } \\
\text { students' } \\
\text { involvement in WIL } \\
\text { in Canada and } \\
\text { Australia }\end{array}$ & $\begin{array}{l}\text { Engineering, } \\
\text { information } \\
\text { technology, } \\
\text { business and } \\
\text { economics } \\
\text { and health } \\
\text { sciences }\end{array}$ & $\begin{array}{l}\text { Semi- } \\
\text { structured } \\
\text { interviews }\end{array}$ & $\begin{array}{l}\text { This study investigated barriers and challenges related to } \\
\text { international students' experiences in Australia (and Canada). } \\
\text { The study interviewed } 10 \text { students ( } 4 \text { in Canada and } 6 \text { in } \\
\text { Australia) and found that WIL helped international students get } \\
\text { exposed to local work culture, workplace etiquette and } \\
\text { behaviours. However, international students faced challenges } \\
\text { including English language proficiency, inadequate } \\
\text { understanding of the attitudes of employers and their } \\
\text { expectations. This study also found that international students } \\
\text { could negotiate the diversity of cultural values, power relations } \\
\text { and norms at workplace if they possessed an agentic disposition. } \\
\text { In contrast, if international students did not have this quality, they } \\
\text { tended to encounter difficulties in obtaining a placement and } \\
\text { deriving the maximum benefit from their WIL experience. }\end{array}$ \\
\hline 4 & $\begin{array}{l}\text { Jackling, B., \& } \\
\text { Natoli, R. (2015) }\end{array}$ & $\begin{array}{l}\text { Employability skills } \\
\text { of international } \\
\text { accounting } \\
\text { graduates: } \\
\text { Internship providers' } \\
\text { perspectives. }\end{array}$ & Accounting & $\begin{array}{l}\text { Semi- } \\
\text { structured } \\
\text { interviews }\end{array}$ & $\begin{array}{l}\text { The research reported the perceptions of internship providers with } \\
\text { respect to the employability skills of international accounting } \\
\text { graduates using a survey. Almost half of the respondents } \\
\text { expressed their concerns about the capacity of international } \\
\text { students to be 'work ready' with respect to business acculturation, } \\
\text { capacity to handle unfamiliar problems and communication skills. }\end{array}$ \\
\hline 5 & Jackson, D. (2016) & $\begin{array}{l}\text { Deepening industry } \\
\text { engagement with } \\
\text { international } \\
\text { students through } \\
\text { work-integrated } \\
\text { learning }\end{array}$ & Business & $\begin{array}{l}\text { Semi- } \\
\text { structured } \\
\text { interviews }\end{array}$ & $\begin{array}{l}\text { This research explored employer, academic, and student } \\
\text { perspectives on the barriers experienced by international } \\
\text { students in gaining exposure to WIL. The findings reported that } \\
\text { international students gained potential benefits including cultural } \\
\text { insights and linguistic expertise. For employers, they could } \\
\text { potentially deepen existing collaborative global partnerships } \\
\text { through the placement of participating international students. } \\
\text { However, a large number of industries expressed their reluctance } \\
\text { in hosting international students. Concerns were often related to } \\
\text { perceived weak oral and (or) written communication skills, which }\end{array}$ \\
\hline
\end{tabular}
Pham. T., Saito, E., Bao, D., \& Chowdhury, R. (2018). Employability of international students: Strategies to enhance their experience on work integrated leaming (WIL) programs. Journal of Teaching and Leaming for
Graduate Employability, 9(1), 62-83. 


\begin{tabular}{|c|c|c|c|c|c|}
\hline & & & & & $\begin{array}{l}\text { may affect discussions with clients and when writing emails or } \\
\text { documents. There were also concerns for cultural differences, } \\
\text { between the home and host countries that may lead to clients' } \\
\text { complaints. }\end{array}$ \\
\hline 7 & $\begin{array}{l}\text { Tran, T. L., \& } \\
\text { Soejatminah, S. } \\
\text { (2016) }\end{array}$ & $\begin{array}{l}\text { 'Get foot in the door': } \\
\text { international } \\
\text { students' } \\
\text { perceptions of work } \\
\text { integrated learning }\end{array}$ & $\begin{array}{l}\text { VET in } \\
\text { various } \\
\text { disciplines } \\
\text { including } \\
\text { hospitality, } \\
\text { nursing, } \\
\text { business, } \\
\text { community } \\
\text { welfare, } \\
\text { building and } \\
\text { carpentry }\end{array}$ & $\begin{array}{l}\text { Semi- } \\
\text { structured } \\
\text { interviews }\end{array}$ & $\begin{array}{l}\text { This paper explored perceptions of international students towards } \\
\text { benefits they gained on in VET. Although international students } \\
\text { experienced linguistic and cultural challenges, the study showed } \\
\text { that WIL was seen to not only add value to student learning, } \\
\text { career aspiration and employability but also transform and } \\
\text { enhance their symbolic and social capitals. WIL was perceived by } \\
\text { those international students as a valuable pathway to developing } \\
\text { knowledge and skills related to their vocational study. WIL was } \\
\text { emphasised as enabling personal learning in addition to } \\
\text { professional learning }\end{array}$ \\
\hline 8 & $\begin{array}{l}\text { Tangen, D., \& } \\
\text { Campbell, M. (2017) }\end{array}$ & $\begin{array}{l}\text { Who fails whom? A } \\
\text { case study } \\
\text { exploration of factors } \\
\text { leading to } \\
\text { unsuccessful } \\
\text { international pre- } \\
\text { service teachers' } \\
\text { work placements }\end{array}$ & Education & $\begin{array}{l}\text { Semi- } \\
\text { structured } \\
\text { interviews }\end{array}$ & $\begin{array}{l}\text { The study explored factors leading to unsuccessful field } \\
\text { placements of four international students. These students were } \\
\text { classified as domestic because they completed their final high } \\
\text { school years in Australia. However, they lacked an understanding } \\
\text { of schooling in Australia and a less than ideal level of English } \\
\text { language proficiency for teaching in Australian schools. They } \\
\text { therefore encountered various problems on placement. The case } \\
\text { studies showed that both individual and systemic considerations } \\
\text { needed to be taken into account in order to attain success. Better } \\
\text { relationships between the international student, their mentor and } \\
\text { the university site were recommended. }\end{array}$ \\
\hline 9 & $\begin{array}{l}\text { Barton, G., Hartwig, } \\
\text { K., Joseph, D., \& } \\
\text { Podorova, A. (2017) }\end{array}$ & $\begin{array}{l}\text { Practicum for } \\
\text { international } \\
\text { students in teacher } \\
\text { education programs: }\end{array}$ & Education & $\begin{array}{l}\text { Semi- } \\
\text { structured } \\
\text { interviews }\end{array}$ & $\begin{array}{l}\text { The study presented case studies from three university sites that } \\
\text { offered international students initial teacher education programs. } \\
\text { The findings revealed that English proficiency was the main issue } \\
\text { facing international students on practicum (placement) and this }\end{array}$ \\
\hline
\end{tabular}
Pham T., Saito, E., Bao, D., \& Chowdhury, R. (2018). Employability of international students: Strategies to enhance their experience on work integrated learning (WIL) programs. Journal of Teaching and Learning for
Graduate Employability, 9(1), 62-83. 


\begin{tabular}{|c|c|c|c|c|c|}
\hline & & $\begin{array}{l}\text { An investigation of } \\
\text { three university sites } \\
\text { through } \\
\text { multisocialisation, } \\
\text { interculturalisation } \\
\text { and reflection }\end{array}$ & & & $\begin{array}{l}\text { limitation had severe impacts on classroom practice. Besides, the } \\
\text { students also faced contextual factors, that is, the differences in } \\
\text { the programs and universities. This had significant impacts on the } \\
\text { outcomes for international students. }\end{array}$ \\
\hline 10 & $\begin{array}{l}\text { Jones, L., } \\
\text { O'Connor, E., Boag- } \\
\text { Hodgson, C. (2017) }\end{array}$ & $\begin{array}{l}\text { Enhancing } \\
\text { workplace learning } \\
\text { for international } \\
\text { students in } \\
\text { psychology: learning } \\
\text { from students' and } \\
\text { supervisors' } \\
\text { perspectives }\end{array}$ & Psychology & $\begin{array}{l}\text { Semi- } \\
\text { structured } \\
\text { interviews }\end{array}$ & $\begin{array}{l}\text { The study conducted interviews with } 10 \text { psychology students from } \\
\text { various Asian countries and their supervisors. These students } \\
\text { came to placement with a particular life history that engendered } \\
\text { particular identities to be salient, as well as particular } \\
\text { subjectivities, that can be termed as potential strengths and } \\
\text { vulnerabilities. Their strengths were their knowledge in } \\
\text { intercultural, personal qualities and transition experiences, while } \\
\text { their vulnerabilities were lack of English competency and } \\
\text { communication, Australian culture, Australian workplaces and } \\
\text { work experience. To support these students, the study } \\
\text { recommended that both the students and workplaces needed to } \\
\text { make efforts and adjustments. }\end{array}$ \\
\hline 11 & $\begin{array}{l}\text { Bennett, D., \& } \\
\text { Ferns, S. (2017) }\end{array}$ & $\begin{array}{l}\text { Functional and } \\
\text { cognitive aspects of } \\
\text { employability: } \\
\text { implications for } \\
\text { international } \\
\text { students }\end{array}$ & Therapy & $\begin{array}{l}\text { Semi- } \\
\text { structured } \\
\text { interviews }\end{array}$ & $\begin{array}{l}\text { The study analysed data from three occupational therapy } \\
\text { international students across a number of work placements. } \\
\text { These students were aware of their weaknesses such as English } \\
\text { proficiency, shortage of local working culture and conventions. } \\
\text { Feedback and support from workplace supervisors featured as a } \\
\text { key component of a quality experience for these international } \\
\text { students, who particularly valued mentors who provided } \\
\text { constructive feedback. When mentors were supportive, the } \\
\text { students made good progress and the outcomes included } \\
\text { acknowledging the need for individual autonomy and reflective } \\
\text { behaviour as critical indicators of learner development. }\end{array}$ \\
\hline
\end{tabular}

Pham. T., Saito, E., Bao, D., \& Chowdhury, R. (2018). Employability of intemational students: Strategies to enhance their experience on work integrated leaming (WIL) programs. Journal of Teaching and Leaming for Graduate Employability, 9(1), 62-83. 


\begin{tabular}{|c|c|c|c|c|c|}
\hline 12 & $\begin{array}{l}\text { Sonnenschein, K., } \\
\text { Barker, M., Hibbins, } \\
\text { R., \& Cain, M. } \\
(2017)\end{array}$ & $\begin{array}{l}\text { Practical experience } \\
\text { is really important: } \\
\text { Perceptions of } \\
\text { Chinese } \\
\text { international } \\
\text { students about the } \\
\text { benefits of work } \\
\text { integrated learning } \\
\text { in their Australian } \\
\text { tourism and } \\
\text { hospitality degrees }\end{array}$ & $\begin{array}{l}\text { Tourism \& } \\
\text { Hospitability }\end{array}$ & $\begin{array}{l}\text { Semi- } \\
\text { structured } \\
\text { interviews }\end{array}$ & $\begin{array}{l}\text { The study included an analysis of } 19 \text { semi-structured interviews } \\
\text { with Chinese international students all enrolled in one university } \\
\text { in Australia to examine their experience in the tourism and } \\
\text { hospitality industries. The students acknowledged industry } \\
\text { experience was important but about half of them considered it a } \\
\text { challenge to find an internship in Australia because of their limited } \\
\text { English skills and because competition for internships was } \\
\text { intense. Eventually, many of them chose internship back in China. }\end{array}$ \\
\hline 13 & Kelly, A. (2017) & $\begin{array}{l}\text { Transforming } \\
\text { challenges into } \\
\text { opportunities: A } \\
\text { work placement } \\
\text { model to help } \\
\text { international } \\
\text { students become } \\
\text { employable }\end{array}$ & Education & $\begin{array}{l}\text { Semi- } \\
\text { structured } \\
\text { interviews }\end{array}$ & $\begin{array}{l}\text { This research presented the perspectives of } 37 \text { students } \\
\text { participating in a large-scope research project on the linguistic } \\
\text { and cultural challenges they faced in their work placements. A } \\
\text { range of English problems facing international students were } \\
\text { reported. Some of these were the shortage of terminology, } \\
\text { unclear communication and writing and the lack of understanding } \\
\text { in local working culture. The study recommended that staff } \\
\text { needed to be more supportive and flexible so that the students } \\
\text { could use their agency on placement. The study also concluded } \\
\text { that international students' challenges can also be viewed as } \\
\text { opportunities and strengths with further intercultural } \\
\text { understanding. Once this approach was taken, it could ensure } \\
\text { that all involved had more positive experiences. }\end{array}$ \\
\hline 14 & Jackson, D. (2017) & $\begin{array}{l}\text { Exploring the } \\
\text { challenges } \\
\text { experienced by } \\
\text { international } \\
\text { students during } \\
\text { work-integrated }\end{array}$ & Business & $\begin{array}{l}\text { Semi- } \\
\text { structured } \\
\text { interviews } \\
\text { and survey }\end{array}$ & $\begin{array}{l}\text { This study explores the challenges experienced by international } \\
\text { students during WIL. Data were gathered from employers }(97) \text {, } \\
\text { academics }(15) \text { and students }(n=56) \text {. The results reported that all } \\
\text { stakeholders identified a number of challenges which impacted on } \\
\text { student performance and the success of their WIL experiences. } \\
\text { Cultural differences and relatively weak language skills were seen }\end{array}$ \\
\hline
\end{tabular}
Pham, T., Saito, E., Bao, D., \& Chowdhury, R. (2018). Employability of intermational students: Strategies to enhance their experience on work integrated leaming (WIL) programs. Journal of Teaching and Leaming for
Graduate Employability, 9(1), 62-83. 


\begin{tabular}{|l|l|l|l|}
\hline & learning in Australia. & & $\begin{array}{l}\text { as major issues facing international students on WIL. Several } \\
\text { strategies were proposed to improve the situation amongst which } \\
\text { preparation in identifying and managing certain cultural } \\
\text { differences and educating international students on what to } \\
\text { expect from the Australian work setting appeared critical, and } \\
\text { providing language support from academics when students were } \\
\text { on was strongly recommended. }\end{array}$ \\
\hline
\end{tabular}

Pham T., Saito, E., Bao, D., \& Chowdhury, R. (2018). Employability of international students: Strategies to enhance their experience on work integrated learning (WIL) programs. Journal of Teaching and Learning for Graduate Employability, 9(1), 62-83. 


\section{Themes and findings}

The findings of the studies in Table 1 clearly show various issues faced by international students in relation to WIL. Amongst a wide range of problems, language barriers and limited understanding of local culture emerged as the two common major issues in all the studies reviewed. These have been widely acknowledged as areas in which international students need additional assistance in order to excel in their studies and to gain the most of their Australian study experiences (Briguglio \& Smith, 2012; Graduate Careers Australia, 2014). In fact, Australian universities have recently been called upon to provide urgent responses to these areas of concern (IEAA, 2016). The section below elaborates on the main issues and discusses initiatives that have been taken as possible solutions.

\section{Language and communication skills}

Needless to say, communication is an important functioning tool in the workplace, especially in today's world when connectivity is growing as a key for success in various areas (Martin \& Rizvi, 2014), creating stronger demands for both teamwork and collaboration. This explains why communication has often been ranked as the top employability skill required by employers (Pham \& Saito, 2018; Blackmore, Gribble \& Rahimi, 2017). Unfortunately, all of the studies reported in Table 1 have evidenced that international students had an inadequate proficiency in English language which caused confusion, miscommunication and incorrect interpretation of mentor's and supervisors' instructions in the workplace (Birrell, Healy, \& Kinnaird, 2007). Consequently, employers have often expressed reluctance in hosting and employing international students (Jackson, 2017). Below are the main linguistic weaknesses of international students in this area. It is worth noting that information reported in the reviewed studies was not comprehensive. To provide further insights about linguistic weaknesses, this paper also draws on evidence provided in studies that were not reviewed in this paper.

\section{'Heavy' accents}

'Different' and 'heavy' accents have been reported as an obstacle for international students in communicating with employers and mentors on WIL (Kelly, 2017). International students tend to have problems with pronouncing sounds and phonemes that do not exist in their language. For instance, Asian students from certain regions often have difficulty with, and inaccurate pronunciation of 'r', 'th', and ' $w$ ' sounds. Some students have been seen to have an 'awkward' accent which can be hard to understand (Barton et al., 2017). Howells, Westerveld and Garvis (2017) provided an example illustrating how even English-speaking students had a problem with understanding some Australians who had an accented way of pronouncing certain vowels. Although debatable, it is commonly agreed that British and American English are the most preferable because these accents are reported as 'clear', 'intelligible' and representative of 'world standards' (Ngoc, 2016). Consequently, research on employment of native and nonnative speakers by $\mathrm{Ngoc}$ (2016) found that employers, learners and academics presented a similar concern that graduates with an accent unfamiliar to British and American English speakers were found to experience difficulties in the workplace. In ELT, teachers who spoke 'non-standard' or 'localised English' were found to have slower promotions on their job (Ngoc, 2016).

\section{Writing and technical terminology}

Gribble and McRae (2015) and Kelly (2017) reported that a significant majority of employers and working supervisors noted written communication and understanding technical 
terminology as two big challenges facing international students. In Kelly's (2017) research, an international student explained that her English was generally seen as 'really good' and 'sufficient', however she lost confidence when writing a proper formal letter or report of a coronial inquest. Acknowledging the existence of such problems, Barton et al. (2017), in a large-scale study with relevant stakeholders including students, supervisors, and international careers and employment officers, attempted to organise extra services and activities for international students to learn commonly used slangs in Australian schools such as 'grab a cuppa', 'calling the roll' and 'put your hands up'.

\section{Limitations of local culture}

Historically, international students have been seen as inferior others (Leask, 2004, p. 186) and a plethora of research has reported on the so-called cultural issues of international students in relation to the various pedagogical practices teachers need to adopt and the supporting services to help them integrate in and adapt to the Australian society (Magyar \& Robinson-Pant, 2011; Sancho, 2008; Barton \& Hartwig, 2017).

When international students participated in WIL, Jackson (2017) found that they lacked familiarity with the Australian culture, work practices, and expectations of different professions. This was evident in their weak understanding of the expected conduct, behaviours, norms and values endemic to the professional setting - such as expectations of employers, established workplace processes, and the hierarchical structure. Jackson (2017) also found that international students in the Health Sciences were not familiar with local jargon, undertaking activities and tasks considered taboo in their own culture, and not fully understanding management hierarchy and organisational structures, leading to confusion and angst among students, clients, and hosts (p.351). In Business courses, students also complained of a lack of appreciation of the funding, logistics, and characteristics of the sector within which they were based, particularly the not-for-profit sector (Jackson, 2017). Jackson further found that a lack of local knowledge among Engineering students raised concerns about expected protocols regarding workplace safety and risk management. From the employer's perspective, there was a reluctance to host international students due to a bias amongst management who may have had preconceptions or previous experiences of their workplace performance - for instance, a male student's reluctance to accept and respect a female manager (Jackson, 2017).

In various studies reported in Table 1 (i.e., Barton et al., 2017; Gribble \& McRae, 2015), international students admitted that adjusting to the Australian work setting - particularly during the early stages of their placement - was challenging. More than half of the international students in a study conducted by Gribble, Blackmore and Rahimi (2015) identified as their first priority, the need for further preparation prior to their placement, relating to professional codes of conduct, workplace ethics, and business etiquette in the Australian workplace. The researchers further suggested that international students should be more versed in the expectations, behaviours, and customs of the Australian workplace and the broader society prior to attending placement.

\section{Discussion}

\section{Who is responsible for addressing international students' language barriers?}

The language problems of international students have commonly been seen as a consequence of their low English entry level to higher education. The Australian Universities Quality Agency (AUQA), which develops English language standards for higher education, has therefore warned that providers need to ensure that students are sufficiently proficient in

Pham T., Saito, E., Bao, D., \& Chowdhury, R. (2018). Employability of international students: Strategies to enhance their experience on work integrated learning (WIL) programs. Joumal of Teaching and Learning for Graduate Employability, 9(1), 62-83. 
English to participate effectively in their higher education studies upon commencement of their studies (Leask, 2004). However, Rochecouste Oliver, Mulligan and Davies (2010), Dunworth (2013) and Wingate (2015) found that admission requirements in themselves were not sufficient to account for proficient communication skills of international students upon completion. A placement officer in a study by Barton et al. (2017) concluded that satisfactory IELTS test scores did not guarantee effective and smooth communication on placement. In fact, if students are well supported by the university, and they demonstrate a strong personal commitment to improvement, lower-entry level students could improve English faster and more naturally than their higher-entry level counterparts.

Other research has shown that international students' poor language is heavily influenced by their lack of efforts in socialising and making friends with local students, leading to their lack of understanding of language protocols and cultural norms and expectations. One explanation for this is that international students are shy, which means they often tend to group together (Sancho, 2008) thereby avoiding opportunities for interaction with 'local' students. In fact, according to Volet and Ang (1998), the lack of interaction between Australian and international students from Asian backgrounds is one of the most disturbing aspects of the internationalisation of Australian university campuses. Colvin, Volet and Fozdar (2014) conducted a series of research studies on improving the interactions of domestic and international students at Australian universities. They found that it was not the international students who could determine the interactions with domestic students, but rather, that the willingness and openness of domestic students played a key role in meaningful interactions between the two parties. The researchers called for the development and utilisation of pedagogical practices that could enhance mutual interactions of international and local students. The cultural orientations in which minority groups like international students are excluded, have been structurally observed to be white, middle-class and male (Read, Archer, \& Leathwood, 2003, p. 271). Although diversity has been advocated as an indispensable element in Australian universities, such discrepant cultural habits have remained prevalent.

\section{Initiatives utilised to support international students improve English proficiency}

To support international students in addressing their language barriers, the common practice that has been widely adopted at Australian universities is providing English language support services (Barton et al., 2017). However, Murray and Arkoudis (2013) found that there is very little evidence about the effectiveness of these services. There are various reasons contributing to this. First, academics or content teachers do not pay enough attention to supporting students because they consider teaching communication skills to be outside both their area of expertise and job description (Dunworth \& Briguglio, 2011). Second, students themselves tend not to attend these extra services because they are busy enough with their disciplinary studies.

The discussion above makes it clear that it is not sufficient for higher education institutions to leave this task to international students alone. A small but increasing number of studies have argued that skills in English as a second or additional language (ESL/EAL) need to be developed through student effort and/or deliberate intervention in teaching and learning (Murray, 2010; Volet \& Ang, 2012, Bretag, 2007). The literature is unequivocal in arguing that high impact student learning occurs when communication skills are integrated and embedded within disciplinary learning and assessment (Arkoudis, Baik, \& Richardson, 2012; Dunworth, 2013; Wingate, 2015). There are a number of studies that provide evidence to support the move in this direction (see for example, Arkoudis, 2014; Briguglio, 2014; Dunworth 2014; Murray \& Nallaya, 2014; Fenton-Smith, Humphreys, Walkinshaw, Michael, \& Lobo, 2015). One strategy would be to embed common vocabularies or terminologies in the field into the

Pham T., Saito, E., Bao, D., \& Chowdhury, R. (2018). Employability of international students: Strategies to enhance their experience on work integrated learning (WIL) programs. Journal of Teaching and Learning for Graduate Employability, 9(1), 62-83. 
courses and units. At this stage, Briguglio (2014) is the only research that has recommended the embedding of referencing conventions and vocabularies into disciplinary/content studies. Howells et al. (2017) claimed that at a program level, at no point are the linguistic differences (e.g. vowels) explicitly discussed with international students during their study program.

It seems that Australia has claimed to be preparing international students for employability a little late, especially when compared with the UK and North America where international students have been found to have better preparation for employability and better dialogues with employers (AUIDF, 2013). The lack of early preparation suggests a disadvantage for international students studying in Australian universities who may not be able to benefit from the positive impacts of professional placement programs like WIL which have been reported to reduce the achievement gaps for minority students in the UK (Moores, Birdi, \& Higson, 2017). If at all, communication and writing skills tend to be only emphasised in later years years 3 \& 4 (Mercer-Mapstone \& Matthews, 2017). Knight (2001) argues that to enable students to develop communication skills, there is a need for long-term planning in which the curriculum needs to be designed with an integration of multiple, consistent and developmental activities that could enable students to practise over time. As such, a more effective strategy would be the design of a comprehensive curriculum that could facilitate students at their very early stage in year 1 to develop both required technical and non-technical skills. Such a curriculum essentially requires the involvement of both disciplinary academics and as well as experts in relevant areas.

\section{Where do cultural issues come from?}

International students have been reported as having limited understanding of local culture. Australian universities have therefore attempted to address this by embedding work conduct and ethics into their programs. However, two questions that need further discussion and more attention are: (1) Why are only international students blamed for these problems? Is this because historically international students have been largely seen as inferior others (Leask, 2004 , p. 186) who need to be filled with Euro-American knowledge (Sancho, 2008), or 'complex others' who have their own identities but still need to assimilate in the Australian academic conventions (Magyar \& Robinson-Pant, 2011)? If this is the case, international students tend to be expected to adjust themselves to fit the conventions on programs; (2) How much can be solved if only international students make efforts? Below is an example illustrating the need for more critical thought about these two questions.

Common comments about international, especially Asian, students on WIL are that they are 'not active', 'unconfident' and 'not critical'. Specifically, Howells et al. (2017) found that workplace supervisors complained that international students, particularly those from Asia, were disengaged because they did not ask questions. This is because asking questions has been considered as an indicator of being critical in Western classrooms (Ryan \& Louie, 2006). The industry has a strong desire for emerging professionals to be critical practitioners who question current practices and challenge the status quo to generate newer ways of thinking, and international students had difficulty engaging with this process in the workplace (Clements \& Cord, 2013). This emerging requirement has actually created an additional challenge for international students because they often struggle with being self-critical and reflecting on personal experience (Campbell \& Zegwaard, 2011).

\section{Strategies to help international students overcome the shortage of local working culture}

Supervisors and industries may interpret Asian students as lacking engagement or interest in what they are doing when they do not ask questions. In fact, this is more related to their cultural

Pham T., Saito, E., Bao, D., \& Chowdhury, R. (2018). Employability of international students: Strategies to enhance their experience on work integrated learning (WIL) programs. Journal of Teaching and Learning for Graduate Employability, 9(1), 62-83. 
norms. Asian students consider asking their supervisor a question as an act of challenging them and a lack of deference to authority (Elliott \& Reynolds, 2014). In fact, the concepts of 'active', 'passive', and 'critical' have attracted lots of attention from researchers. Jin and Cortazzi (1995) point out that these terms are often interpreted differently, depending on the expectations of the 'culture of learning' into which one has been socialised. In recent times the idea of using Vygotskian notions of language as the tool for thought has become very popular, especially in Western discourses. In Western classrooms, talk or verbal participation are seen as pathways to a critical questioning approach (Ryan \& Louie, 2006) and 'learner-centred' pedagogies are designed to encourage students to learn by participating, through talking and active involvement' (Jin \& Cortazzi, 1995, p. 6). This explains why Western employers have implicit and explicit preferences for these activities and expect their employees to actively engage in these practices. If students and employees are not verbally participatory, they are very likely to be seen as problematic.

Such a view of 'effective' learning contrasts with the more cognitive-centred, learning-listening approach that is largely favoured by Asian learners (Jin \& Cortazzi, 1995, p. 744). Within this tradition, being 'active' suggests cognitive involvement, lesson preparation, reflection and review, thinking, memorisation and self-study (Cortazzi \& Jin, 1996, p. 71). Therefore, Littlewood (2000) claims that Asian classrooms may indeed appear relatively 'static' in comparison to those of the Anglophone West. However just because the students operate in a receptive mode does not imply that they are any less engaged. Conversely, just because students in Anglophone Western classrooms are seen to be verbally participatory, this does not necessarily guarantee that learning is actually taking place. For instance, in their study Volet and Kee (1993) reported that Asian students found it astonishing and culturally inappropriate when Australian students interrupted someone who was talking to make a point or asking very simple questions when they could just have kept quiet and found out from their classmates at a later time.

As such, it appears that each specific learning context has its own explicit and tacit rules to define what should be called 'active', 'critical', and 'confident'. In the long run, there is an urgent need for Australian higher education to embed such diverse perspectives into disciplinary programs so that all graduates, and later future employers have a better understanding about how non-technical skills are perceived in various contexts. Undertaking a commitment to internationlising the curriculum may enable this goal to be achieved. In Australia, a wide range of strategies (i.e., student mobility, strengthening domestic-international student interactions) have developed to diversify and internationalise higher education curricula and pedagogies (Nagaraja \& McAllister, 2015). However, the internationalisation of education in Australia should not only stop at introducing cultural topics such as foods and clothes to domestic students, but needs to embed intellectual resources of other countries (i.e., concepts, ideologies) in their current pedagogies and curricula (Kapoor, 2010; Goody, 2010; Singh, 2009). Scholarly literature has documented several forms of pedagogies related to legitimatising marginalised knowledge. For example, Moll, Amanti, Neff and Gonzalez (1992) developed the 'funds of knowledge' approach requiring teachers to bring minority students' prior knowledge into the mainstream curriculum. Other researchers, by using the socio-cultural perspective, further argue for the deployment of culturally appropriate pedagogies to transfer new knowledges into the existing curriculum (e.g., Pham, 2014; Zipin, 2005).

Several studies reviewed in this research (i.e., O'Reilly \& Milner, 2015; Tangen \& Campbell, 2017; Jones et al., 2017) have evidenced that when mentors and employers were open to accepting and supporting diversity, international students were encouraged to complete their placement successfully. In return, industries also had greater potential to develop their businesses globally (Sonnenschein et al., 2017).

Pham T., Saito, E., Bao, D., \& Chowdhury, R. (2018). Employability of international students: Strategies to enhance their experience on work integrated learning (WIL) programs. Joumal of Teaching and Learning for Graduate Employability, 9(1), 62-83. 


\section{Conclusion}

This paper has contributed to an understanding of the issues facing international students during their WIL placements and in their endeavours to find employment. This issue has gathered attention since the Australian Government changed its migration policy to address a skills shortage over the last two decades. The process started with the liberalisation of the study-migration pathway in late 1990s with the intention of allowing international students to apply for permanent residency if they obtained a local qualification. However, a large number of international students failed to find a job in their discipline mainly because they did not meet the requirements of employers. One of the most common reasons for this was unsatisfactory English proficiency. In 2007, the Government therefore lifted the level of English for international students who wanted to apply for permanent residency. However, the situation did not improve because a large number of international students still failed to secure a job at a time when the country faced a shortage of skilled workers. More recently, the Australian Government has prioritised employer-sponsored migrants, although in reality very few employers are willing to sponsor international students mainly because international students are still often perceived as insufficiently qualified by employers due to various reasons including the issues related to culture and language. This study has confirmed that if international students are expected to improve their language skills without support, then the potential for them to contribute to the Australian economy and society will be seriously diminished.

As with employers, there is also a need to rethink how much international students should obey and follow local workplace ethics, conduct and management styles. It has been widely reported that so-called marginalised countries have a rich body of philosophical and ethicalsocio-political thought. India is a clear example of being widely recognised for its rich science, philosophy, literature and critical theories. These intellectual qualities are helping many of these countries develop their economies over Western nations - China is a clear example. International students are nurtured with these intellectual heritages, so surely they possess and could access them while working in Australia. It is timely for current and future employers in Australia to rethink and make use of these marginalised ways of thought and working. Indeed, employers need to recognise that the notion of employability is vastly different across different countries and cultures with some more focused on discipline content whereas others, including Australia, place more emphasis on developing non-technical skills and gaining relevant work experience. As such, Australian employers need to work out what is a good balance between technical qualities and non-technical capabilities.

This paper has made a contribution to the literature on the experience of international students and especially to the strategies that could assist international students to overcome their disadvantages when participating in WIL. While some of the findings may not be new they are a timely reminder of the need to remain cognisant of the issues related to international students and their WIL experiences. It is acknowledged that the review in this paper may not represent all that has been reported about international students on WIL, especially since information in internal reports of companies hosting WIL students was not available. Since only published sources were included, it is also acknowledged that a few unpublished theses in the field may provide further insights in the future. Finally, it is recognised that this paper only included research conducted in Australia rather than in other countries.

Pham T., Saito, E., Bao, D., \& Chowdhury, R. (2018). Employability of international students: Strategies to enhance their experience on work integrated learning (WIL) programs. Journal of Teaching and Learning for Graduate Employability, 9(1), 62-83. 


\section{References}

ABC News (2015). Fact check: How many students leave higher education with STEM qualifications? Retrieved from http://www.abc.net.au/news/2015-10-23/fact-check-billshorten-stem-qualifications-australia/6828470 on January 20, 2018.

Anderson, P., \& Green, P. (2006). (L)earning for employability, lessons for HE?. Paper presented at Social diversity and difference: Influence on participation, learning and teaching in HE seminar series, seminar 5 employment. University of Wolverhampton: Science Park, Wolverhampton.

Arkoudis, S. (2014). Integrating English language communication skills into disciplinary curricula: Options and strategies. Sydney: Office for Learning and Teaching. Retrieved from www.cshe.unimelb.edu.au/arkoudis_fellowship.

Arkoudis, S., Baik, C., \& Richardson, S. (2012). English language standards in higher education. Melbourne: ACER.

Australian Universities (2017). Retrieved from http://www.australianuniversities.com.au/directory/international-student-numbers/ on September 20, 2017.

AUIDF (2013). Improving the employment outcomes of international students. Melbourne: Prospect Research and Marketing.

Barton, G., \& Hartwig, K. (2017). The Importance of positive intercultural exchanges for international students on work placements in higher education. In G. Barton, \& K. Hartwig (Eds.), Professional learning in the work place for international students: Exploring theory and practice (pp. 3-12). Cham, Switzerland: Springer.

Barton, G., Hartwig, K., Bennett, D., Cain, M., Campbell, M., Ferns, S., Jones, L., Joseph, D., Kavanagh, M., Kelly, A., Larkin, I., O’Connor, E., Podorova, A., Tangen, D., \& Westerveld, M. (2017). Work placement for international student programs (WISP): A model of effective practice. In G. Barton, \& K. Hartwig (Eds.), Professional learning in the work place for international students: Exploring theory and practice (pp. 13-34). Cham, Switzerland: Springer.

Barton, G., Hartwig, K., Joseph, D., \& Podorova, A. (2017). Practicum for international students in teacher education programs: An investigation of three university sites through multisocialisation, interculturalisation and reflection. In G. Barton, \& K. Hartwig (Eds.), Professional learning in the work place for international students: Exploring theory and practice (pp. 129-146). Cham, Switzerland: Springer.

Bennett, D., \& Ferns, S. (2017). Functional and cognitive aspects of employability: Implications for international students. In G. Barton, \& K. Hartwig (Eds.), Professional learning in the work place for international students: Exploring theory and practice (pp. 203-222). Cham, Switzerland: Springer.

Bines, H., \& Watson, D. (1992). Developing professional education. Buckingham: Society for Research into Higher Education and Open University Press.

Birrell B., Healy, E., \& Kinnaird, B. (2007). Cooks galore and hairdressers aplenty. People and Place, 15(1), 30-44.

Blackmore, J., Gribble, C., \& Rahimi, M. (2017). International education, the formation of capital and graduate employment: Chinese accounting graduates' experiences of the Australian labour market. Critical Studies in Education, 58(1), 69-88, doi: 10.1080/17508487.2015.1117505

Bowen, G. A. (2009). Document analysis as a qualitative research method. Qualitative Research Journal, 9(2), 27-40. doi:10.3316/QRJ0902027

Pham T., Saito, E., Bao, D., \& Chowdhury, R. (2018). Employability of international students: Strategies to enhance their experience on work integrated learning (WIL) programs. Joumal of Teaching and Learning for Graduate Employability, 9(1), 62-83. 
Bretag, T. (2007). The emperor's new clothes: Yes, there is a link between English language competence and academic standards. People and Place, 15(1), 13-21.

Briguglio, C. (2014). Working in the third space: Promoting interdisciplinary collaboration to embed English language development into the disciplines. Sydney: Office for Learning and Teaching.

Brigulio, C., \& Smith, R. (2012). Perceptions of Chinese students in an Australian university: Are we meeting their needs? Asia Pacific Journal of Education, 32(1), 17-33. doi:10.1080/02188791.2012.655237

Campbell, M., \& Zegwaard, K. E. (2011). Ethical considerations and workplace values in cooperative and work-integrated education. In R. K. Coll \& K. E. Zegwaard (Eds.), International handbook for cooperative and work-integrated education: International perspectives of theory, research and practice (2nd ed., pp. 363-369). Lowell, MA: World Association for Cooperative Education.

Castle, A., Holloway, D., \& Race, A. (1998). A review of issues in continuing professional development in teaching, nursing and radiography. International Journal of Lifelong Learning, 17(5) 328-40. doi:10.1080/0260137980170505

Clements, M. D., \& Cord, B. A. (2013). Assessment guiding learning: Developing graduate qualities in an experiential learning program. Assessment and Evaluation in Higher Education, 38(1), 114-124.

Colvin, C., Volet, S., \& Fozdar, F. (2014). Local university students and intercultural interactions: Conceptualising culture, seeing diversity and experiencing interactions. Higher Education Research \& Development, 33(3), 440-455. doi:10.1080/07294360.2013.841642

Cortazzi, M., \& Jin, L. (1996). Cultures of learning: Language classrooms in China. In H. Coleman (Ed.), Society and the language classroom (pp. 169-206). Cambridge: Cambridge University Press.

Crebert, G., Bates, M., Bell, B., Patrick, C.J., \& Cragnolini, V. (2004). Developing generic skills at university, during work placement and in employment: graduates' perceptions. Higher Education Research and Development, 3(2),147-165. doi:10.1080/0729436042000206636

Creswell, J. (1998). Qualitative inquiry and research design: Choosing among five traditions. Thousand Oaks, CA: Sage.

Department of Education and Training (DET) (2015). Draft Strategy for International Education. DET: Canberra. Retrieved from https://internationaleducation.gov.au/Internationalnetwork/Australia/InternationalStrategy/Documents/Draft\%20National\%20Strategy\%20fo r\%20International\%20Education.pdf on January 20, 2018.

Dunworth, K. (2013). Discussion paper 2: In-course student English language development. In Five years on: English language competence of international students - Outcomes Report. Retrieved from www.ieaa.org.au/documents/item/54 on December 20, 2017.

Dunworth, K. (2014). Degrees of proficiency: Building a strategic approach to university students' English language assessment and development (Final Report). Sydney: Office for Learning and Teaching.

Dunworth, K., \& Briguglio, C. (2011). Teaching students who have English as an additional language: A handbook for academic staff in higher education. Milperra, New South Wales: HERDSA.

Elliott, C. J., \& Reynolds, M. (2014). Participative pedagogies, group work and international classroom: An account of students' and tutors' experiences. Studies in Higher Education, 39(2), 307-320. doi: 10.1080/03075079.2012.709492

Pham T., Saito, E., Bao, D., \& Chowdhury, R. (2018). Employability of international students: Strategies to enhance their experience on work integrated learning (WIL) programs. Journal of Teaching and Learning for Graduate Employability, 9(1), 62-83. 
Fenton-Smith, B., Humphreys, P., Walkinshaw, I., Michael, R., \& Lobo, A. (2015).

Implementing a university-wide credit-bearing English language enhancement program: Issues emerging from practice. Studies in Higher Education, 42(3), 1-17.

doi:10.1080/03075079.2015.1052736

Goody, J. (2010). The Eurasian Miracle. Cambridge and Malden: Polity Press.

Graduate Careers Australia (2014). Employment for new graduates: Slow but Steady. GCA: Melbourne.

Gribble, C. (2014). Employment, work placements and work integrated learning of international students in Australia. Research Digest Series. IEAA: Melbourne.

Gribble, C., \& Blackmore, J. (2012). Re-positioning Australia's international education in global knowledge economies: Implications of shifts in skilled migration policies for universities. Journal of Higher Education Policy and Management, 34(4), 341-354. doi:10.1080/1360080X.2012.689181

Gribble, C., \& McRae, N. (2015). Creating a climate for global WIL: Barriers to participation and strategies for enhancing international students' involvement in WIL in Canada and Australia. In G. Barton, \& K. Hartwig (Eds.), Professional learning in the work place for international students: Exploring theory and practice (pp. 35-56). Cham, Switzerland: Springer.

Gribble, C., Blackmore, J., \& Rahimi, M. (2015). Challenges to providing work integrated learning to international business students at Australian universities. Higher education, skills and work-based learning, 5(4), 401-416. doi: 10.1108/HESWBL-04-2015-0015

Griffiths, T., \& Guile, D. (2003). A connective model of learning: The implications for work process knowledge. European Educational Research Journal, 2(1), 56-73. doi:10.2304/eerj.2003.2.1.10

Group and Australian Collaborative Education Network (2015). National strategy on work integrated learning in university. Retrieved from http://cdn1.acen.edu.au/wpcontent/uploads/2015/03/National-WIL-Strategy-in-university-education-032015.pdf on November 20, 2017.

Hattie, J., Marsh, H.W., Neill, J.T., \& Richards, G. E. (1997). Adventure education and Outward Bound: Out-of-class experiences that make a lasting difference. Review of Educational Research, 67, 43-87. doi:10.3102/00346543067001043

Hawthorne, L. (2014). Indian students and the evolution of the study-migration pathway in Australia. International Migration, 52(2), 3-19. doi:10.1111/imig.2014.52

Howells, S., Westerveld, M., \& Garvis, S. (2017). Revisiting cultural and linguistic diversity in speech pathology programs in Australia: Listening to the voices of staff and international students. In G. Barton, \& K. Hartwig (Eds.), Professional learning in the work place for international students: Exploring theory and practice (pp. 165-182). Cham, Switzerland: Springer.

Humphreys, P., Greenan, K., \& Mcllveen, H. (1997). Developing work-based transferable skills in a university environment. Journal of European Industrial Training, 21(2), 63-69. doi:10.1108/03090599710161739

International Education Association of Australia (IEAA) (2016). Mobility for Social Change: IEAA Mobility Forum 2016. IEAA: Melbourne.

Jackling, B., \& Natoli, R. (2015). Employability skills of international accounting graduates internship providers' perspectives. Education + Training, 57(7), 757-773. doi:

10.1108/ET-08-2014-0093

Jackson, D. (2016). Deepening industry engagement with international students through work-integrated learning. Australian Bulletin of Labour, 42(1), 24-38.

Jackson, D. (2017) Exploring the challenges experienced by international students during

Pham T., Saito, E., Bao, D., \& Chowdhury, R. (2018). Employability of international students: Strategies to enhance their experience on work integrated learning (WIL) programs. Journal of Teaching and Learning for Graduate Employability, 9(1), 62-83. 
work-integrated learning in Australia. Asia Pacific Journal of Education, 37(3), 344-359, doi: 10.1080/02188791.2017.1298515

Jin, L., \& Cortazzi, M. (1995). A cultural synergy model for academic language use. In P. Bruthiaux, T. Boswood, \& B. Du-Babcock (Eds.), Explorations in English for professional communication (p.41-56). Hong Kong: University of Hong Kong.

Jones, L., O'Connor, E., Boag-Hodgson, C. (2017). Enhancing workplace learning for international students in psychology: Learning from students' and supervisors' perspectives. In G. Barton, \& K. Hartwig (eds.), Professional learning in the work place for international students: Exploring theory and practice (pp. 183-202). Cham, Switzerland: Springer.

Kapoor, K. (2010). The humanities and the social sciences in India. Prabuddha Bharata. Retrieved from www.advaitaashrama.org on December 20, 2017.

Kelly, A. (2017). Transforming challenges into opportunities: A work placement model to help international students become employable. In G. Barton, \& K. Hartwig (Eds.), Professional learning in the work place for international students: Exploring theory and practice (pp. 299-312). Cham, Switzerland: Springer.

Knight, P.T. (2001). Complexity and curriculum: A process approach to curriculum-making. Teaching in Higher Education, 6(3), 371-383. doi:10.1080/13562510120061223

Leask, B (2004). Transnational education and intercultural learning: Reconstructing the offshore teaching team to enhance internationalisation. AUQA Occasional Publication, Proceedings of the Australian Universities Quality Forum 2004. Australia: AUQA Occasional Publication.

Little, B., \& Harvey, L. (2006). Learning through work placements and beyond. The higher education careers services unit and the higher education academy's work placements organisation forum: Manchester.

Littlewood, W. (2000). Do Asian students really want to listen and obey? ELT Journal, 54(I), 31-36.

Magyar, A., \& Robinson-Pant, A. (2011). Internationalising doctoral research: Developing theoretical perspectives on practice. Teachers and Teaching: Theory and Practice, 17(6), 663-677.

Martin, F., \& Rizvi, F. (2014). Making Melbourne: Digital connectivity and international students' experience of locality. Media, Culture and Society, 36(7), 1016-1031. doi: $10.1177 / 0163443714541223$

Mercer-Mapstone, L. D., \& Matthews, K. E. (2017). Student perceptions of communication skills in undergraduate science at an Australian research-intensive university. Assessment and Evaluation in Higher Education, 42, 98-114. doi:10.1080/02602938.2015.1084492

Minister for Innovation, Industry, Science and Research (2011). A research workforce strategy. Australian Government. Retrieved from https://industry.gov.au/AboutUs/CorporatePublications/AnnualReports/AnnualReport200 910/Chapter_6_Department_outcome_2.html

Moll, L., Amanti, C., Neff, D., \& Gonzalez, N. (1992). Funds of knowledge for teaching. Theory into Practice, 2, 132-141.

Moores, E., Birdi, G., \& Higson, H. (2017). Placement work experience may mitigate lower achievement levels of black and Asian vs. white students at university. Frontiers in. Psychology, 8, 1518.https://doi.org/10.3389/fpsyg.2017.01518

Murray, D., \& Arkoudis, S. (2013). Discussion paper 1: Preparation and selection. In Five years on: English language competence of international students - Outcomes Report. Retrieved from http://www.ieaa.org.au/documents/item/54 on November 20, 2017.

Pham T., Saito, E., Bao, D., \& Chowdhury, R. (2018). Employability of international students: Strategies to enhance their experience on work integrated learning (WIL) programs. Journal of Teaching and Learning for Graduate Employability, 9(1), 62-83. 
Murray, N. (2010). Conceptualising the English language needs of first year university students. The International Journal of the First Year in Higher Education, 1(1), 55-64.

Murray, N., \& Nallaya, S. (2014). Embedding academic literacies in university program curricula: A case study. Studies in Higher Education, 41(7), 1296-1312. doi:10.1080/03075079.2014.981150

Nagarajan, S., \& Mc Allister, L. (2015). Internationalisation of curriculum: Imperatives, opportunities and challenges for allied health education. Journal of Teaching and Learning for Graduate Employability, 6(1), 88-99.

Ngoc, B. D. (2016). To employ or not to employ expatriate non-native speaker teachers: Views from within. Asian Englishes, 18(1), 67-79. doi:10.1080/13488678.2015.1132112

Nicholls, E., \& Walsh, M. (2007). University of Wolverhampton case study: Embedding practical work-based modules into a traditionally theoretical program. Education \& Training, 49(3), 201-209. doi:10.1108/00400910710749332

Nicol, R. (2013). Returning to the richness of experience: Is auto ethnography a useful approach for outdoor educators in promoting pro-environmental behaviour? Journal of Adventure Education and Outdoor Learning, 13(1), 3-17. doi:10.1080/14729679.2012.679798

O'Reilly, S., \& Milner, J. (2015). Supporting culturally and linguistically diverse students during clinical placement: Strategies from both sides of the table. BMC Medical Education, 15(175), 1-12, doi: 10.1186/s12909-015-0458-3

Orrell, J. (2011). Good practice report: Work-integrated learning. Canberra: Australian Learning and Teaching Council. Retrieved from www.

olt.gov.au/system/files/resources/GPR Work Integrated_Learning_Orrell_2011.pdf on October 20, 2017.

Patrick, C. J., Peach, D., Pocknee, C., Webb, F., Fletcher, M., \& Pretto, G. (2008). The WIL (work integrated learning) report: A national scoping study [Final Report]. Brisbane: Australian Learning and Teaching Council.

Pham, T. (2014). Implementing cross-culture pedagogies: Cooperative learning at Confucian heritage cultures. Singapore: Springer.

Pham, T., \& Saito, E. (In press). Teaching towards graduates attributes: Is this a solution for employability of university students in Australia? In B. Hong, \& D. Coles, Innovate higher education to enhance graduate employability. UK: Higher Education Academy.

Raelin, J. (2010). Work-based learning in US higher education policy. Higher Education, Skills and Work-based Learning, 1(1), 10-15. doi:10.1108/20423891111085357

Read, B., Archer, L., \& Leathwood, C. (2003). Challenging cultures? Student conceptions of 'belonging' and 'isolation' at a post-1992 university. Studies in Higher Education, 28(3), 261-277. doi: 10.1080/03075070309290

Reddy, P., \& Moores, E. (2012). Placement year academic benefit revisited: Effects of demographics, prior achievement and degree program. Teaching in Higher Education, 17(2), 153-165. doi:10.1080/13562517.2011.611873

Rochecouste, J., Oliver, R., Mulligan, D., \& Davies, M. (2010). Addressing the ongoing English language growth of international students. Sydney: ALTC.

Roddick, D. (2014). The answer to teacher shortages. Retrieved from https://www.teachermagazine.com.au/articles/home-and-away-the-answer-to-teachershortages on October 22, 2017.

Ryan, G., Toohey, S., \& Hughes, C. (1996). The purpose, value and structure of the practicum in higher education: A literature review. Higher Education, 31(3), 355-377. doi:10.1007/BF00128437 
Ryan, J., \& Louie, K. (2006). False dichotomy? 'Western' and 'Confucian' concepts of scholarship and learning. Educational Philosophy and Theory, 39(4), 404--417. doi:10.1111/j.1469-5812.2007.00347.x

Sancho, J. (2008). Opening students' minds: Educational technology in a growing internationalized world. In M. Hellstén \& A. Reid (Eds.), Researching international pedagogies (pp. 259-276). The Netherlands: Springer.

School Governance (2016). High teacher attrition rate causes fear of teacher shortage. Retried from https://www.schoolgovernance.net.au/2016/01/21/high-teacher-attritionrate-causes-fear-of-teacher-shortage/ October 23, 2017.

Singh, M. (2010). Connecting intellectual projects in China and Australia. Australian Journal of Education, 54(1), 31-45. doi:10.1177/000494411005400104

Sonnenschein, K., Barker, M., Hibbins, R., \& Cain, M. (2017). Practical experience is really important: Perceptions of Chinese international students about the benefits of work integrated learning in their Australian tourism and hospitality degrees. In G. Barton \& K. Hartwig (Eds.), Professional learning in the work place for international students: Exploring theory and practice (pp. 259-275). Cham, Switzerland: Springer.

Steedman, H., Gospel, H., \& Ryan, P. (1998). Apprenticeship: A strategy for growth. London: Centre for Economic Performance. London School of Economics and Political Science.

Tangen, D., \& Campbell, M. (2017). Who fails whom? A case study exploration of factors leading to unsuccessful international pre-service teachers' work placements. In G. Barton, \& K. Hartwig (Eds.), Professional learning in the work place for international students: Exploring theory and practice (pp. 75-91). Cham, Switzerland: Springer.

Teacher (2014). The answer to teacher shortages. Retrieved from https://www.teachermagazine.com.au/articles/home-and-away-the-answer-to-teachershortages on December 25, 2017.

Tran, L., \& Soejatminah, S. (2016). 'Get foot in the door': International students' perceptions of work integrated learning. British Journal of Educational Studies, 64(3), 337-355. doi: 10.1080/00071005.2015.1128526

Volet, S., \& Ang, G. (2012). Culturally mixed groups on international campuses: An opportunity for intercultural learning. Higher Education Research and Development, 31(1), 21-37. doi:10.1080/07294360.2012.642838

Volet, S. E., \& Ang. G. (1998). Culturally mixed groups on international campuses: An opportunity for inter-cultural learning. Higher Education Research and Development, 17(1), 5-23.

Volet, S. E., \& Kee, J. P. P. (1993). Studying in Singapore and studying in Australia: A student perspective. Occasional Paper No 1, Murdoch University Teaching Excellence Committee, Murdoch.

Wingate, U. (2015). Academic literacy and student diversity: The case for inclusive practice. UK: Multilingual Matters.

Zipin, L. (2005). Dark funds of knowledge, deep funds of pedagogy: Exploring boundaries between lifeworlds and schools. Discourse: Studies in the Cultural Politics of Education, 30(3), 317-331. 